\title{
Molecular, physiological, and agronomical characterization, in greenhouse and in field conditions, of soybean plants genetically modified with $A t G o l S 2$ gene for drought tolerance
}

\author{
Patricia T. Honna • Renata Fuganti-Pagliarini • Leonardo C. Ferreira • \\ Mayla D. C. Molinari - Silvana R. R. Marin - Maria C. N. de Oliveira • \\ José R. B. Farias • Norman Neumaier • Liliane M. Mertz-Henning • \\ Norihito Kanamori • Kazuo Nakashima • Hironori Takasaki • \\ Kaoru Urano • Kazuo Shinozaki • Kazuko Yamaguchi-Shinozaki • \\ Janete A. Desidério • Alexandre L. Nepomuceno
}

Received: 15 April 2016 / Accepted: 6 October 2016 / Published online: 12 November 2016

(C) Springer Science+Business Media Dordrecht 2016

\begin{abstract}
Water deficit may occur at any stage of crop development, affecting productivity and causing economic losses. In response to drought, raffinose family
\end{abstract}

Patricia T. Honna and Renata Fuganti-Pagliarini contributed equally.

Electronic supplementary material The online version of this article (doi:10.1007/s11032-016-0570-z) contains supplementary material, which is available to authorized users.

P. T. Honna · J. A. Desidério

Department of Applied Biology to Farming, FCAV-UNESP, Jaboticabal, SP, Brazil

P. T. Honna · R. Fuganti-Pagliarini • M. D. C. Molinari Embrapa Soybean, Rodovia Carlos João Strass, Acesso Orlando Amaral, Warta, Coordination for the Improvement of Higher Education Personnel (CAPES), PO. Box 231 86001-970,

Londrina, PR, Brazil

\section{C. Ferreira}

Embrapa Soybean, Rodovia Carlos João Strass, Acesso Orlando Amaral, Warta, National Council for Scientific and Technological Development (CNPq), PO. Box 231 86001-970, Londrina, PR, Brazil

S. R. R. Marin · M. C. N. de Oliveira · J. R. B. Farias ·

N. Neumaier · L. M. Mertz-Henning •

A. L. Nepomuceno $(\triangle)$

Embrapa Soybean, Rodovia Carlos João Strass, Acesso Orlando Amaral, Warta, PO. Box 231 86001-970, Londrina, PR, Brazil

e-mail: alexandre.nepomuceno@embrapa.br oligosaccharides (RFOs) are accumulated in plant tissues stabilizing and protecting cell membranes and keeping the vital functions. The enzyme galactinol
M. D. C. Molinari

Department of General Biology, Londrina State University, Londrina, PR, Brazil

N. Kanamori · K. Nakashima

Biological Resources and Post-harvest Division, Japan

International Research Center for Agricultural Sciences, Tsukuba, Ibaraki, Japan

H. Takasaki · K. Urano • K. Shinozaki

Gene Discovery Research Group, RIKEN Center for Sustainable Resource Science, Tsukuba, Ibaraki, Japan

K. Yamaguchi-Shinozaki

Laboratory of Plant Molecular Physiology, The University of

Tokyo, Bunkyo-ku, Tokyo, Japan

Present Address:

H. Takasaki

Laboratory of Plant Molecular Physiology, The University of

Tokyo, Bunkyo-ku, Tokyo, Japan 
synthase (GolS, EC 2.4.1.123) catalyzes the first step in the biosynthesis of RFOs. In our study, soybean events overexpressing 35S:AtGolS2 were molecularly, physiological, and agronomical characterized, under drought simulated in greenhouse and in field conditions during the crop season 2014/2015. The conventional soybean cultivar BRS 184 was transformed and five positive events were obtained. Four events transmitted the transgene to further generations and in the events 2Ia1 and 2Ia4, two to four copies of AtGols2 gene were observed. Results in greenhouse showed that the overexpression of AtGolS2 in genetically modified (GM) plants led to increased galactinol transcripts, probably resulting in changes in carbohydrate metabolism. Accumulation of these transcripts that may have acted as osmoprotectors, lead to higher drought tolerance and survival rate of 2Ia4 plants. In addition, in field conditions, higher yield was observed for 2Ia4 plants under irrigated (IRR) and nonirrigated (NIRR) treatments. This result can be due to the increased synthesis of RFOs even under wellwatered conditions. This field screening showed promising results for drought tolerance, suggesting that 2Ia4 plants may be useful in a breeding program for the development of drought-tolerant plants. However, additional studies are needed in further crop seasons and other sites to better characterize how these plants may outperform the WT plants under water deficit.

Keywords Glycine max L. Merrill · Abiotic stresses · Galactinol synthase $\cdot$ Raffinose

\section{Introduction}

Soybean is an important oilseed crop worldwide and a primary source of fat and vegetable protein both for human nutrition and animal feed (Wang et al. 2015). Furthermore, its use for biodiesel is increasing in the last years. As an important worldwide commodity, soybean is not exempt from the problems arising from water deficit, and so is not Brazil, one of the few countries that could considerably increase its production in the next decades.

Drought has been responsible for decreasing considerably the grain yield worldwide, mainly during the reproductive phase, when total production can be reduced by up to $40 \%$ (Tran et al. 2010; Hu and Xiong 2014). In the last decades, drought events frequency and intensity are increasing, probably due to global climatic changes, drawing a future scenario where arable areas and productivity might be affected, threatening food security worldwide and increasing worldwide financial prejudices, thus development of drought-tolerant crops is gaining prominence in scientific research areas.

In response to environmental changes, plants developed a set of morphological, physiological, biochemical, cellular, and molecular mechanisms to cope and deal metabolically with water deficit periods (Fang and Xiong 2015). Among the products of genes involved in the response to abiotic stresses, such as drought, osmoprotectors molecules such as sugars (trehalose, sucrose, and fructose), amino acids (proline and tryptophan), and ammonium compounds (polyamines and glycyl betaine) accumulate in plants under adverse conditions, and are mainly related to the osmotic adjustment process, which acts as an adaptive mechanism reducing the osmotic potential, increasing cellular water retention, and delaying senescence and death (Turner et al. 2001; Chaves et al. 2003; Chaves and Oliveira 2004).

Acting as osmoprotectants, raffinose family oligosaccharides (RFOs), such as raffinose, stachyose, and verbascose, are known to be involved in response to adverse environmental conditions. In drought tolerance, RFOs are able to regulate the osmotic potential, and protect enzymes and membranes from different environmental stresses such as cold, heat, and dehydration (Crowe et al. 1984; Wang et al. 2004). The key enzyme in the production of RFOs is galactinol synthase (Gols, EC 2.4.1.123), synthesizing galactinol from UDPgalactose and myo-inositol (Panikulangara et al. 2004; Pattanagul and Madore 1999). GolS genes were reported to be upregulated by abiotic stress treatment in many plant species. Takahashi et al. (1994) reported that OsGols messenger RNA (mRNA) accumulated in response to cold and to osmotic stress in rice seedlings (Oryza sativa). In Arabidopsis thaliana, AtGolS1 and AtGols2 mRNAs were detected in mature seeds and induced by water and salt stress in the leaves and the AtGolS3 mRNA was induced by cold (Taji et al. 2002). In tomato (Lycopersicon esculentum Mill. cv Moneymaker), the accumulation of LeGols-1 mRNA was induced by dehydration but not by cold in germinating seeds (Downie et al. 2003). In Vitis vinifera, VvGolS1 was upregulated by high temperature (Pillet et al. 2012) and, in Salvia miltiorrhiza, SmGolS genes presented differential expression in response to hormone, cold, and heat treatments 
(Wang et. 2012). Furthermore, in Medicago falcata, MfGolS1 was induced by cold, and overexpression of MfGolS1 in tobacco resulted in elevated tolerance to freezing and chilling in transgenic plants (Zhuo et al. 2013). In Coffea arabica, analysis indicated that the genes CaGolS were differentially regulated under water deficit, high salt, and heat stress (dos Santos et al. 2011). The transcriptional profile of a Coffea canephora galactinol synthase gene (CcGolS1) also indicated that the expression of $C c G o l S 1$ in leaves was differentially regulated by water deficit, depending on the intensity of stress and the genotype (dos Santos et al. 2015). In Populus tricocarpa, GolS (PtrGolS) genes were differentially expressed in different organs and abiotic stresses, with induction of PtrGolS by salt stress only in the early period of treatment (within $24 \mathrm{~h}$ ), whereas water deficit stress treatments continued to upregulate PtrGolS gene expression for 2 days after the induction of treatment (Zhou et al. 2014). In soybean, submitted to water deficit, Marcolino and co-workers (2014) described a diurnal oscillation and induced expression for $\mathrm{GmGols}$ like gene. Gene expression quantification for soybean GolS (Glyma19g40680) confirmed the expression induction in plants submitted to water deficit (Rodrigues et al. 2015).

All these reports in many plant species show promising results with GolS genes to improve abiotic stresses tolerance; however, all data were obtained in greenhouse conditions. According to Passioura (2012), the results obtained under controlled conditions may not be well connected to the way that plants behave over the entire season in the real field situation. Additionally, tests in the field are a legal requirement from the Brazilian National Technical Biosafety Commission to approve a commercial product. Thus, considering the urgent need of drought-tolerant soybean plants to secure food production in the next decades, and the need for understanding with respect to the mechanisms of tolerance of GolS transgenic plants performing under a real crop season, the present study aimed to introduce, via Agrobacterium tumefaciens, the gene construct 35S:AtGolS2 in a conventional soybean cultivar and molecularly characterize the obtained events regarding the relative expression and number of transgene inserted copies. Furthermore, we characterized the expression profile of the inserted transgene and of genes codifying RFOs, as well as the lines for growth, physiological, and agronomical parameters under water deficit induced in greenhouse and field experiments.

\section{Material and methods}

Transformation, identification of positive events, and segregation pattern

The expression cassette containing the AtGolS2 gene was constructed with pMDC123-GI and pC3300J-35S vectors (Cambia Enabling Innovation 2012) and introduced, via electroporation, into the A. tumefaciens strain EHA 105 (Hood et al. 1993), as described by Casali and Preston (2003). This vector is under the control of the constitutive promoter CaMV 35S (Cauliflower mosaic virus) and TNOS terminator (A. tumefaciens nopaline synthase). Two marker genes are also present in the cassette structure: the bar gene (phosphinothricin acetyl transferase), which confers resistance to the herbicide ammonium glufosinate, used as a selective agent; and the NPTII gene (Neomycin phosphotransferase), which confers resistance to the antibiotic kanamycin, used to select the colonies containing the inserted transgene.

Genetic transformation was performed using soybean cotyledonary nodes from the conventional cultivar BRS 184, according to the method described by Paz et al. (2006). A modification was introduced aiming to improve injury for infection; thus, each cotyledon was scratched 10 to 12 times, using a stainless steel micro brush.

Seedlings that developed during the selection process were transferred to one substrate mixture containing substrate/sand (1:1), with a substrate containing soil/sand/organic compounds (3:2:2); these were kept in a growing chamber for acclimation for at least 1 week. Next, the seedlings were transferred to a greenhouse and were molecularly evaluated.

To confirm possible positive events, genomic DNA from plantlets was extracted using the protocol described by Doyle and Doyle (1987) and a conventional PCR using specific primers for the inserted gene AtGols2 (forward 5'-cccTCTAGAATGGCACC TGAGATCAATAC-3' and reverse 5'-cccGGATCCCT AAGCTGCAGATGGAGCTT-3') was carried out. The PCR reaction was performed in a final volume of $25 \mu \mathrm{L}$, and composed of $5 \mu \mathrm{M}$ of each forward and reverse primer, $0.4 \mathrm{mM}$ dNTPs, $2 \mathrm{mM}$ magnesium chloride, $1 \mathrm{U}$ Taq DNA polymerase, and $50 \mathrm{ng} \mu \mathrm{L}^{-1}$ of DNA. Amplifications were performed in a Veritti (Applied 
Biosystems) thermocycler using the following cycling parameters: an initial denaturation at $95{ }^{\circ} \mathrm{C}$ for $5 \mathrm{~min}$, followed by 35 cycles of $95{ }^{\circ} \mathrm{C}$ for $30 \mathrm{~s}, 59^{\circ} \mathrm{C}$ for $30 \mathrm{~s}$, and $72{ }^{\circ} \mathrm{C}$ for 30 s, with a final elongation cycle of $72{ }^{\circ} \mathrm{C}$ for $7 \mathrm{~min}$.

To analyze the segregation pattern in the generated events, plants from $T_{1}$ and $T_{2}$ generations were analyzed by conventional PCR to confirm the presence of the transgene. The $X^{2}$ test $(p \leq 0.05)$ was conducted to determine whether the AtGolS2 gene was segregating in agreement with the expected Mendelian pattern.

\section{Quantification of transgene copy number via qPCR}

Quantification of the transgene-inserted copy was performed using AtGolS2 as the target gene and the Lec gene (GmLec, Accession No. K00821), a soybean species-specific gene presenting only one copy in the haploid genome (Meyer et al. 1994), or two allelic copies (homozygous), as the endogenous and calibrator gene. All primers were designed with the aid of the Primer-BLAST program (http://www.ncbi.nlm.nih. gov/tools/primer-blast/ and are described in Supplementary Table S1).

For both the target and calibrator genes, an amplification efficiency curve was created using a series of DNA dilutions $\left(5^{-6}, 5^{-5}, 5^{-4}, 5^{-3}\right.$, and $\left.5^{-2}\right)$. Amplification reactions were comprised of the DNA dilutions (one reaction for each), $0.2 \mu \mathrm{M}$ of $\mathrm{F}$ and $\mathrm{R}$ primers, and $1 \times$ reaction buffer Platinum $\AA$ SYBR Green $®$ qPCR SuperMix UDG (Invitrogen) composed of Taq DNA polymerase, Tris- $\mathrm{HCl}, \mathrm{KCl}, 6 \mathrm{mM} \mathrm{MgCl} 2,400 \mu \mathrm{M}$ dGTP, $400 \mu \mathrm{M}$ dATP, $400 \mu \mathrm{M}$ dCTP, $800 \mu \mathrm{M}$ dUTP, uracil DNA glycosylase (UDG), and stabilizers. Reactions were conducted in three biological and three technical triplicates in the 7900HT (Applied Biosystems) thermocycler, following the cycling parameters: $50{ }^{\circ} \mathrm{C}$ for $2 \mathrm{~min}$, denaturation at $95^{\circ} \mathrm{C}$ for $10 \mathrm{~min}$, followed by 40 cycles of $95{ }^{\circ} \mathrm{C}$ for $15 \mathrm{~s}$ and $60{ }^{\circ} \mathrm{C}$ for $1 \mathrm{~min}$. To calculate the reaction efficiency, the formula $E=[10-1 /$ slope] -1 (Pfaffl 2001) was applied. To quantify the number of copies of the AtGolS2 gene inserted into the soybean genome, $\mathrm{Ct}$ values from the target gene were subtracted from the $\mathrm{Ct}$ of the endogenous reference gene (lectin) in each sample, resulting in the $\Delta \mathrm{Ct}$ value. The calculation of the number of copies is 2 elevated to the average of $-\Delta \mathrm{Ct}\left(2^{-\Delta \mathrm{Ct}}\right)$, where 2 corresponds to the sum of the target gene efficiency $(100 \%=1)$ and the endogenous control $(100 \%=1)$, and varies according to the primer efficiency in the amplification reaction.

Analysis of gene expression by RT-qPCR

Genes AtGols2 (AT1G56600.1), GmRS1 (Glyma03g29440), GmRS3 (Glyma19g00441), LEA2 (Glyma09g31740), and LEA6 (Glyma17g17860) (Supplementary Table S1) were selected for expression analysis. Total RNA was extracted using Trizol@ reagent and complementary DNA (cDNA) synthesized using SuperScript ${ }^{\circledR}$ III First-Strand Synthesis System (Invitrogen/ Catalog number: 180800) according to the manufacturer's instructions. Relative quantification of gene expression was performed in three biological and three technical $(n=9)$. The reactions were composed of the cDNAs, $0.2 \mu \mathrm{M}$ of $\mathrm{F}$ and $\mathrm{R}$ primers, and $1 \times$ reaction buffer Platinum ${ }^{\circledR}$ SYBR Green ${ }^{\circledR}$ qPCR SuperMix UDG (Invitrogen). Reactions were conducted on the 7900HT thermo cycler (Applied Biosystems) following the same cycling conditions as those described above. The constitutive expression of the AtGolS2 gene was obtained by the $\Delta \mathrm{Ct}$ value using the endogenous reference gene $G m \beta$-actin gene. In addition, for the expression analysis, the $\Delta \mathrm{Ct}$ values from each sample under water deficit were subtracted from the $\Delta \mathrm{Ct}$ value of the calibrator sample, corresponding to the same sample under control conditions, resulting in the $\Delta \Delta \mathrm{Ct}$ value. This value was used in the formula $2^{-\Delta \Delta \mathrm{Ct}}$, as previously described.

Experiments with GM lines submitted to water deficit under greenhouse conditions

Thirty seeds of the $T_{2}$ generation from the events 2Ia1 and 2Ia4, and from the conventional soybean cultivar BRS 184 (wild type, WT) were treated with Vitavax ${ }^{\circledR}$ Thiram $200 \mathrm{SC}\left(200 \mathrm{~g} \mathrm{~L}^{-1}\right)$ (ADAPAR) for health quality purposes, then allowed to germinate on Germitest ${ }^{\circledR}$ paper for $96 \mathrm{~h}$ at $25^{\circ} \mathrm{C} \pm 1$ and at $100 \%$ relative humidity $(\mathrm{RH})$. Seedlings were transferred to 1-1 pots filled with substrate mixture (composition mentioned previously), each pot contained only one seedling. All seedlings were kept in a greenhouse at $28 \pm 2{ }^{\circ} \mathrm{C}$, with temperature and $\mathrm{RH}$ recorded every 5 min through a thermohygrograph (Hobo U14-002, Onset $\left.{ }^{\circledR}\right)$. The experimental design was completely randomized, with split-plots and nine replications. The plant materials were distributed in the plots, while the 
water conditions (water deficit-WD; control-C) were distributed in the subplots.

To identify positive plants, a conventional PCR using primers specific for the transgene when plants reached the developmental stage V1 (Fehr et al. 1971) was carried out. Pots were kept at $100 \%$ field capacity (FC) through daily irrigation with a fixed water volume that was sufficient to saturate the substrate until plants reached the phenological stage V4 (26 days after sowing, DAS). At this stage, 1 day before WD induction, all pots were saturated with water at the end of the afternoon to allow the water excess to be drained overnight. On the following morning, pots were wrapped in polyethylene bags and the central region of the pots was covered with cotton around the stem base in order to prevent water loss by evaporation. Control plants were kept at $100 \% \mathrm{FC}$, while irrigation was withheld in the WD group, which was monitored daily in relation to the stomatal conductance $\left(g_{s}\right)$. When WD plants showed $g_{s}$ values less than $200 \mathrm{mmol} \mathrm{H}_{2} \mathrm{O} \mathrm{m}^{-2} \mathrm{~s}^{-1}$ (Flexas et al. 2004; Salinet 2009), which occurred 8 days after irrigation withholding, gas exchange parameters - photosynthetic rate $(A)$, sub-stomatal $\mathrm{CO}_{2}(C i)$, stomatal conductance $\left(g_{s}\right)$-were measured on the central leaflet of the third fully-expanded trifoliate leaf (apex-base direction) through a portable infrared gas analyzer (LCpro-SD, ADC BioScientific) in three different plants. Measurements were performed inside the greenhouse from 9:00 a.m. at $1000 \mu \mathrm{mol} \mathrm{m} \mathrm{m}^{-2} \mathrm{~s}^{-1}$ photosynthetically active radiation (PAR). Thereafter, the same trifoliate leaf was sampled, wrapped in aluminum foil, immersed in liquid nitrogen, and stored at $-80{ }^{\circ} \mathrm{C}$ for the analysis of gene expression by RT-qPCR.

After gas exchange measurements and trifoliate leaf sampling for gene expression analysis, all plants were transferred to 8-1 pots filled with a substrate composed of soil-sand-organic compound (3:2:2) and kept under continuous irrigation until the end of the cycle, when some agronomical parameters (per plant) were evaluated: number of pods presenting seeds, number of pods without seeds, total dry matter of seeds, total number of seeds, number of seeds per pod, and 1000-seed weight.

The growth analysis experiment was design in randomized blocks, in a $3 \times 2$ (plant materials-2Ia1, 2Ia4, and WT BRS $184 \times$ water conditions - C and WD) factorial arrangement. After 8 days of irrigation withholding, we counted the number of nodes and measured the total leaf area using a leaf area meter (LI-3100C model, Licor), which was defined as the sum of areas from all leaf blades in each plant. Leaf blades, stems plus petioles, and roots were sampled and dried in a forced aeration oven at $60{ }^{\circ} \mathrm{C}$ until obtaining constant weight for quantification of their dry matter, so that the total dry matter (per plant) corresponded to the sum of dry matter from the different tissues. Plant height was measured in the beginning (H1) and at the end (H2) of WD induction. The mean length of internodes corresponded to the ratio between $\mathrm{H} 2$ and the number of nodes. From both plant height measurements, we calculated the relative growth rate in height (RGRH), according to the equation: RGRH $(\%)=[((\mathrm{H} 2-\mathrm{H} 1) /$ $\left.\mathrm{H} 1)^{*} 100\right]$. The gravimetric moisture of the substratesand mixture $(\mathrm{GrM})$ was obtained from the equation: $\operatorname{GrM}(\%)=100 *[(\mathrm{CW}+\mathrm{MMS})-(\mathrm{CW}+\mathrm{MDS}) /(\mathrm{CW}+$ MDS)-CW], where $\mathrm{CW}$ is the can weight (g), MMS is the mass of moist soil ( $\mathrm{g}$ ), and MDS is the mass of dried soil (g) obtained after substrate drying at $110{ }^{\circ} \mathrm{C}$.

The experiment for survival rate analysis and daily transpiration measurement was designed in randomized blocks, with eight blocks. Plants were kept at $100 \%$ FC until reaching stage $\mathrm{V} 3$, when WD was induced in all plants, as previously described. Irrigation withholding lasted for 20 days and, during this period, pots were weighed daily from 9:00 a.m. in order to obtain the daily transpiration $\left(\mathrm{g} \mathrm{day}^{-1}\right)$ by the loss of water between consecutive days. When $90 \%$ of BRS 184 plants had died, all plants were re-watered (100\% FC) for 8 days, i.e., until the plants showed evident leaf turgor recovery. Then, the percentage of surviving plants was counted.

Agronomical parameters of GM lines submitted to water deficit under field conditions

The experiment was carried out in the field area located in the National Soybean Research Center $\left(63^{\circ} 11^{\prime} \mathrm{S}, 51^{\circ}\right.$ $11^{\prime} \mathrm{W}, 630 \mathrm{~m}$ altitude) belonging to the Brazilian Agricultural Research Corporation (Embrapa Soybean, Londrina, PR, Brazil) during the crop season 2014/2015. All necessary documentation to test genetically modified (GM) lines in field conditions were submitted and approved by the National Technical Biosafety Commission (CTNBio) (Process n ${ }^{\circ} 01200.003132 /$ 2014-11 published in the Brazilian Official Journal on September 09th, 2014 by the number 4.188/2014).

A randomized complete block split-plot design was used, with four blocks. Plots corresponded to four water conditions - irrigated (IRR, water from precipitation + irrigation when the matric potential of soil water was between 
-0.03 and $-0.05 \mathrm{MPa}$ ), non-irrigated (NIRR, water from precipitation), and an environment covered with rainout shelters programmed to move in the presence of rainfall $( \pm 0.02 \mathrm{~mm})$ in order to simulate drought conditions and induce water deficit in plants in the vegetative (DSV) and reproductive (DSR) periods. Subplots corresponded to the conventional cultivar BRS 184 and its isoline, the transgenic line 2Ia4 GolS2. The area of each subplot was $220 \mathrm{~m}^{2}$ in IRR and NIRR conditions, and $60 \mathrm{~m}^{2}$ under DSV and DSR. Seeds were sown on November 6th, 2014 with $0.5 \mathrm{~m}$ spacing between rows and maintenance of 16 plants $\mathrm{m}^{-1}$. In the DSV treatment, water from precipitation was withheld from December 5th, 2014 to January 5th, 2015, while DSR corresponded to water withholding between January 5th, 2015 and the harvest period (March 1st-April 13th, 2015).

Cultivation conditions followed the procedures routinely adopted at Embrapa Soybean. Plants of the soybean cultivar BRS 360RR were used as a 10-m isolation border, following the Brazilian legislation. Air temperature and relative air humidity were monitored on a daily basis by a weather station located near the experimental area. At the end of the cycle, plants were evaluated regarding number and dry matter of seeds and pods with seeds, 100-seed weight and yield. The sequential water balance was calculated according to Thornthwaite and Mather (1955).

The percentage contents of protein and oil in the samples of soybean grains at harvest were determined in whole seeds and grains using the reflectance technique of near infrared (NIR) according to Heil (2010).

\section{Statistical analysis}

The residuals showed normal distribution and met other assumptions of the analysis of variance (ANOVA). Thus, data of gas exchange, growth and agronomical parameters, and gravimetric moisture were submitted to ANOVA and means compared by the Tukey test $(p \leq 0.05)$.

\section{Results}

Identification of positive plants, segregation analyses, and quantification of inserted copies number

A total of 339 cotyledons from the soybean conventional cultivar BRS 184 were transformed, via $A$. tumefaciens, with the 35S:AtGolS2 construction. Five positive events were identified in the $\mathrm{T}_{0}$ generation. A transformation efficiency of $1.47 \%$ was obtained, considering the total number of fertile transgenic plants divided by the total number of explants transformed ( 5 positive events/339 processed samples) (Rech et al. 2008).

Four independent events, 2Ia1, 2Ia2, 2Ia3, and 2Ia4, transmitted the AtGolS2 gene to generation $\mathrm{T}_{1}$, but only 2Ia1 and 2Ia4 events transferred the transgene to the $\mathrm{T}_{2}$ generation (Supplementary Table S2).

Based on the segregation analysis, it was observed for the 2Ial event in the $\mathrm{T}_{1}$ generation that all plants were positive; however, in the $\mathrm{T}_{2}$ generation, the segregation ratio observed was $2: 1$. In contrast, a Mendelian segregation ratio was observed for the 2Ia2, 2Ia3, and 2Ia4 events in the $\mathrm{T}_{1}$ generation and for the 2Ia4 event in the $\mathrm{T}_{2}$ generation (Supplementary Table S2).

In the current study, 2-4 copies were observed for the events 2Ia1 and 2Ia4 (Supplementary Table S3). Based on the results of segregation and seed production in the $\mathrm{T}_{2}$ generation, two events (2Ia1-8 and 2Ia4-11) were selected to evaluate the effect of AtGolS2 gene insertion in the soybean genome, under drought conditions. In subsequent evaluations, plants will be annotated only as 2Ia1 and 2Ia4.

Relative expression of transgene AtGolS2 and induced genes in soybean plants submitted to water deficit

Higher expression level for the AtGolS2 gene was detected in the 2Ial event (nine times higher expression compared to the reference $G m \beta$-actin gene), followed by the 2Ia4 event (four times higher expression). WT BRS 184 did not show transgene expression (Fig. 1a). Under water deficit, however, higher relative expression was identified to 2Ia4 event followed by a lower gene expression in plants from event 2Ia1 (Fig. 1b).

Considering endogenous genes, higher levels were identified to $2 \mathrm{Ia} 4$ event (Fig. 1c-f). The raffinose 1 gene (GmRS1-Glyma03g29440) showed a 1.5× increase in expression level, in plants from event 2Ia4, which were submitted to drought conditions, when compared to BRS 184 (Fig. 1c). The increase in the expression level was higher for raffinose 3 gene (GmRS3-Glyma19g00441) with $2 \mathrm{Ia} 4$ event showing $4.5 \times$ higher expression when compared to WT plants (Fig. 1d). The event 2Ia4 also showed higher expression under drought for LEA genes, when compared to BRS 184 , with $1.2 \times$ and $1.14 \times$ higher 


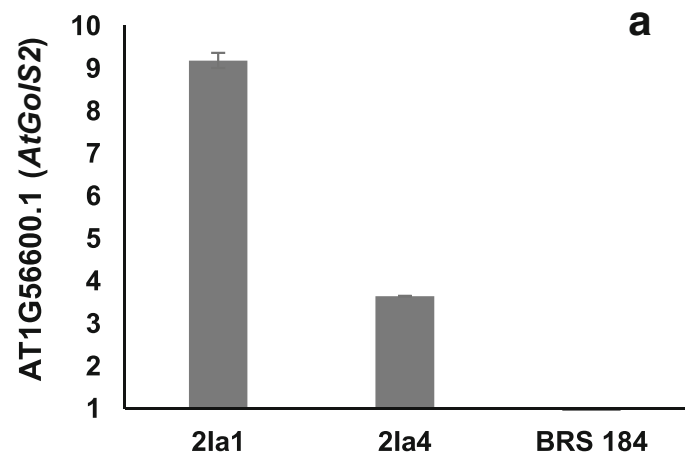

$\square \mathrm{C} \backsim$ WD

b
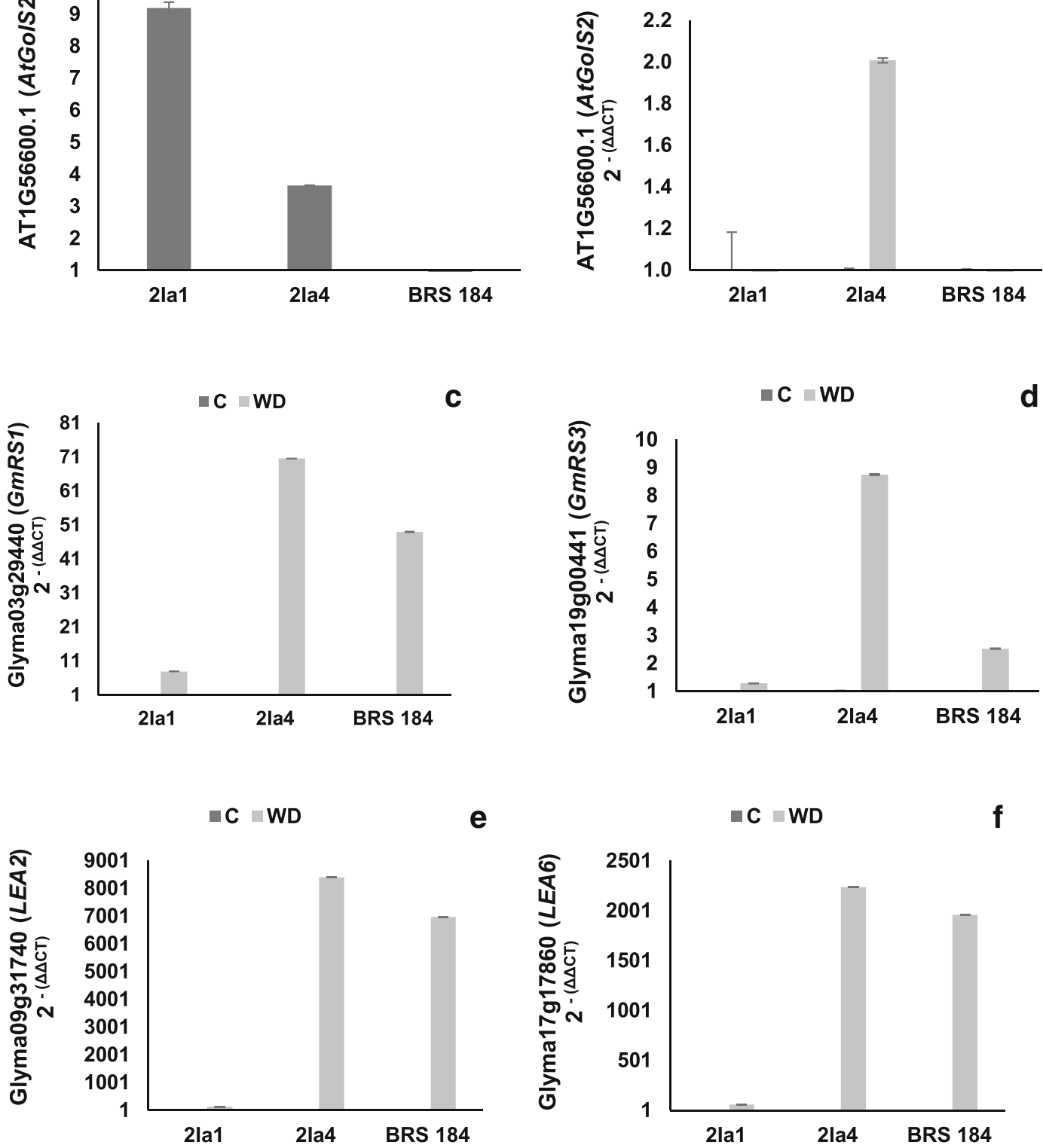

Fig. 1 The constitutive expression (C) of AtGolS2 (a), and the relative expression level of AtGolS2 (b), GmRS1 (c), GmRS3 (d), $L E A 2$ (e), and LEA6 (f) genes in GM events 2Ia1 and 2Ia4 and BRS 184 soybean conventional cultivar under control $(C)$ and

expression, respectively, for $L E A 2$ (Glyma09g31740) and LEA6 (Glyma17g17860) (Fig. 1e and Fig. 1f).

Gas exchange measurements and gravimetric moisture

There was significant interaction between plant materials and water conditions for $C i$ and gravimetric water deficit $(W D)$ conditions. Transgene expression was normalized using $G m \beta$-actin gene and calibrated using the same sample under control conditions (without water deficit induction). Values represents means \pm standard error; $n=9$

moisture (GrM), while no significant interaction was observed for $g_{s}$ and $A$ (Table 1). Lower values were observed in all plants under WD, regardless of the plant material evaluated, except regarding $\mathrm{Ci}$. In turn, except for gravimetric moisture, 2Ia4 plants showed higher values under WD relative to the other plant materials (Fig. 2). 
Table 1 Analysis of variance for physiological and phenotypic evaluations in soybean plants (X) genetically modified with the construction AtGolS2 and their parental — cultivar BRS 184 — under different water conditions (Y)

\begin{tabular}{|c|c|c|c|c|c|c|c|}
\hline Variables & Effects & $F$ & $\operatorname{Pr}>F$ & Variables & Effects & $F$ & $\operatorname{Pr}>F$ \\
\hline \multirow[t]{3}{*}{$g_{s}$} & $\mathrm{X}$ & 3.37 & $0.0521 \mathrm{NS}$ & NPPS (G) & $\mathrm{X}$ & 6.95 & $0.0024^{\mathrm{a}}$ \\
\hline & $\mathrm{Y}$ & 17.32 & $0.0004^{\mathrm{a}}$ & & $\mathrm{Y}$ & 17.47 & $0.0001^{\mathrm{a}}$ \\
\hline & $\mathrm{X}^{* \mathrm{Y}}$ & 0.37 & $0.6921 \mathrm{NS}$ & & $\mathrm{X}^{* \mathrm{Y}}$ & 8.88 & $0.0006^{\mathrm{a}}$ \\
\hline \multirow[t]{3}{*}{$\mathrm{Ci}$} & X & 6.82 & $0.0045^{\mathrm{a}}$ & NPWS (G) & $\mathrm{X}$ & 3.61 & $0.0351^{\mathrm{a}}$ \\
\hline & $\mathrm{Y}$ & 1.82 & $0.1903 \mathrm{NS}$ & & $\mathrm{Y}$ & 0.02 & $0.8968 \mathrm{NS}$ \\
\hline & $\mathrm{X}^{*} \mathrm{Y}$ & 3.82 & $0.0371^{\mathrm{a}}$ & & $\mathrm{X}^{*} \mathrm{Y}$ & 0.58 & $0.5629 \mathrm{NS}$ \\
\hline \multirow[t]{3}{*}{$A$} & $\mathrm{X}$ & 0.67 & $0.5208 \mathrm{NS}$ & TDMS (G) & $\mathrm{X}$ & 3.19 & $0.0502 \mathrm{NS}$ \\
\hline & $\mathrm{Y}$ & 35.65 & $<0.0001^{\mathrm{a}}$ & & $\mathrm{Y}$ & 14.76 & $0.0004^{\mathrm{a}}$ \\
\hline & $X * Y$ & 0.28 & $0.7561 \mathrm{NS}$ & & $\mathrm{X} * \mathrm{Y}$ & 4.81 & $0.0127^{\mathrm{a}}$ \\
\hline \multirow[t]{3}{*}{ GrM } & $\mathrm{X}$ & 59.83 & $<0.0001^{\mathrm{a}}$ & TNS (G) & $\mathrm{X}$ & 3.53 & $0.0375^{\mathrm{a}}$ \\
\hline & $\mathrm{Y}$ & 257.96 & $<0.0001^{\mathrm{a}}$ & & $\mathrm{Y}$ & 17.56 & $0.0001^{\mathrm{a}}$ \\
\hline & $X * Y$ & 70.50 & $<0.0001^{\mathrm{a}}$ & & $\mathrm{X} * \mathrm{Y}$ & 5.52 & $0.0071^{\mathrm{a}}$ \\
\hline \multirow[t]{3}{*}{ LBDM } & $\mathrm{X}$ & 8.80 & $0.0018^{\mathrm{a}}$ & NSPP (G) & $X$ & 0.04 & $0.9624 \mathrm{NS}$ \\
\hline & $\mathrm{Y}$ & 52.32 & $<0.0001^{\mathrm{a}}$ & & $\mathrm{Y}$ & 1.22 & $0.2757 \mathrm{NS}$ \\
\hline & $X * Y$ & 5.07 & $0.0166^{\mathrm{a}}$ & & $X * Y$ & 0.46 & $0.6342 \mathrm{NS}$ \\
\hline \multirow[t]{3}{*}{ SPPDM } & $\mathrm{X}$ & 8.80 & $0.0018^{\mathrm{a}}$ & 1000SW (G) & $\mathrm{X}$ & 2.99 & $0.0601 \mathrm{NS}$ \\
\hline & $\mathrm{Y}$ & 46.87 & $<0.0001^{\mathrm{a}}$ & & $\mathrm{Y}$ & 0.82 & $0.3694 \mathrm{NS}$ \\
\hline & $\mathrm{X}^{* \mathrm{Y}}$ & 0.62 & $0.5475 \mathrm{NS}$ & & $\mathrm{X}^{* \mathrm{Y}}$ & 0.24 & $0.7904 \mathrm{NS}$ \\
\hline \multirow[t]{3}{*}{$\mathrm{RDM}$} & $\mathrm{X}$ & 9.26 & $0.0014^{\mathrm{a}}$ & NPWS (F) & $\mathrm{X}$ & 53.82 & $0.0000^{\mathrm{a}}$ \\
\hline & $\mathrm{Y}$ & 16.75 & $0.0006^{\mathrm{a}}$ & & $\mathrm{Y}$ & 20.59 & $0.0000^{\mathrm{a}}$ \\
\hline & $\mathrm{X}^{*} \mathrm{Y}$ & 6.89 & $0.0053^{\mathrm{a}}$ & & $\mathrm{X}^{*} \mathrm{Y}$ & 3.10 & $0.0484^{\mathrm{a}}$ \\
\hline \multirow[t]{3}{*}{ TDM } & $X$ & 8.33 & $0.0023^{\mathrm{a}}$ & DMPWS (F) & $\mathrm{X}$ & 68.73 & $0.0000^{\mathrm{a}}$ \\
\hline & $\mathrm{Y}$ & 27.69 & $<0.0001^{\mathrm{a}}$ & & $\mathrm{Y}$ & 8.78 & $0.0006^{\mathrm{a}}$ \\
\hline & $X * Y$ & 4.17 & $0.0031^{\mathrm{a}}$ & & $\mathrm{X} * \mathrm{Y}$ & 1.29 & $0.3040 \mathrm{NS}$ \\
\hline \multirow[t]{3}{*}{$\mathrm{NN}$} & $\mathrm{X}$ & 0.45 & $0.6453 \mathrm{NS}$ & NS (F) & $\mathrm{X}$ & 49.55 & $0.0000^{\mathrm{a}}$ \\
\hline & $\mathrm{Y}$ & 2.39 & $0.1379 \mathrm{NS}$ & & $\mathrm{Y}$ & 16.29 & $0.0000^{\mathrm{a}}$ \\
\hline & $X * Y$ & 5.52 & $0.0123^{\mathrm{a}}$ & & $\mathrm{X} * \mathrm{Y}$ & 3.15 & $0.0463^{\mathrm{a}}$ \\
\hline \multirow[t]{3}{*}{ MLI } & $\mathrm{X}$ & 5.83 & $0.0101^{\mathrm{a}}$ & DMS (F) & $\mathrm{X}$ & 70.08 & $0.0000^{\mathrm{a}}$ \\
\hline & $\mathrm{Y}$ & 18.02 & $0.0004^{\mathrm{a}}$ & & $\mathrm{Y}$ & 10.00 & $0.0003^{\mathrm{a}}$ \\
\hline & $X^{* Y}$ & 0.31 & $0.7362 \mathrm{NS}$ & & $X^{* Y}$ & 1.32 & $0.2931 \mathrm{NS}$ \\
\hline \multirow[t]{3}{*}{ LA } & $\mathrm{X}$ & 0.42 & $0.6626 \mathrm{NS}$ & 100SW (F) & $\mathrm{X}$ & 23.33 & $0.0001^{\mathrm{a}}$ \\
\hline & $\mathrm{Y}$ & 61.02 & $<0.0001^{\mathrm{a}}$ & & $\mathrm{Y}$ & 15.88 & $0.0000^{\mathrm{a}}$ \\
\hline & $\mathrm{X}^{*} \mathrm{Y}$ & 0.91 & $0.4170 \mathrm{NS}$ & & $\mathrm{X}^{*} \mathrm{Y}$ & 3.60 & $0.0305^{\mathrm{a}}$ \\
\hline \multirow[t]{3}{*}{ RGRH } & $X$ & 6.27 & $0.0065^{\mathrm{a}}$ & $\mathrm{Y}(\mathrm{F})$ & $\mathrm{X}$ & 12.92 & $0.0017^{\mathrm{a}}$ \\
\hline & $\mathrm{Y}$ & 6.95 & $0.0145^{\mathrm{a}}$ & & $\mathrm{Y}$ & 95.37 & $0.0000^{\mathrm{a}}$ \\
\hline & $X * Y$ & 1.82 & $0.1833 \mathrm{NS}$ & & $\mathrm{X} * \mathrm{Y}$ & 0.44 & $0.7283 \mathrm{NS}$ \\
\hline
\end{tabular}

$N S$ non-significant, $g_{s}$ stomatal conductance, $\mathrm{Ci}$ sub-stomatal $\mathrm{CO}_{2}, A$ photosynthetic rate, $G r M$ gravimetric moisture of the substrate-sand mixture, $L B D M$ leaf blade dry matter, $S P P D M$ stem plus petiole dry matter, $R D M$ root dry matter, $T D M$ total dry matter, $N N$ number of nodes, $M L I$ mean length of internodes, $L A$ leaf area, $R G R H$ relative growth rate in height, NPPS number of pods presenting seeds, NPWS number of pods without seeds, TDMS total dry matter of seeds, TNS total number of seeds, NSPP number of seeds per pod, $1000 S W 1000$ seed weight, NPWS number of pods with seeds, DMPWS dry matter of pods with seeds, NS number of seeds, DMS dry matter of seeds, 100SW 100-seed weight, $Y$ yield, $(G)$ greenhouse, $(F)$ field

${ }^{\text {a }}$ Significant at $p \leq 0.05$ 


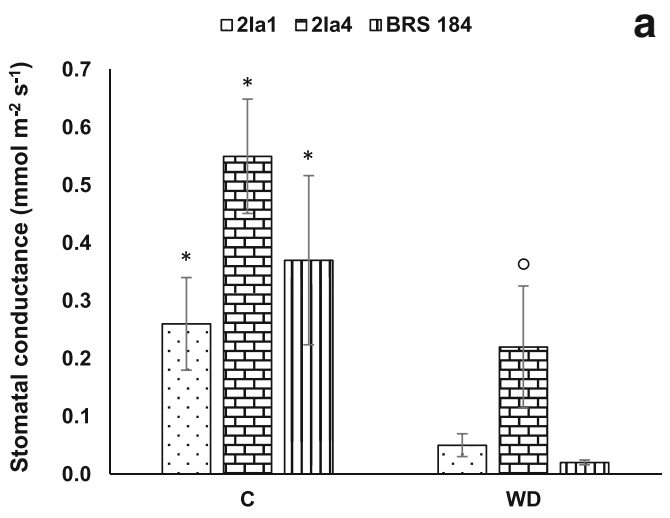

a
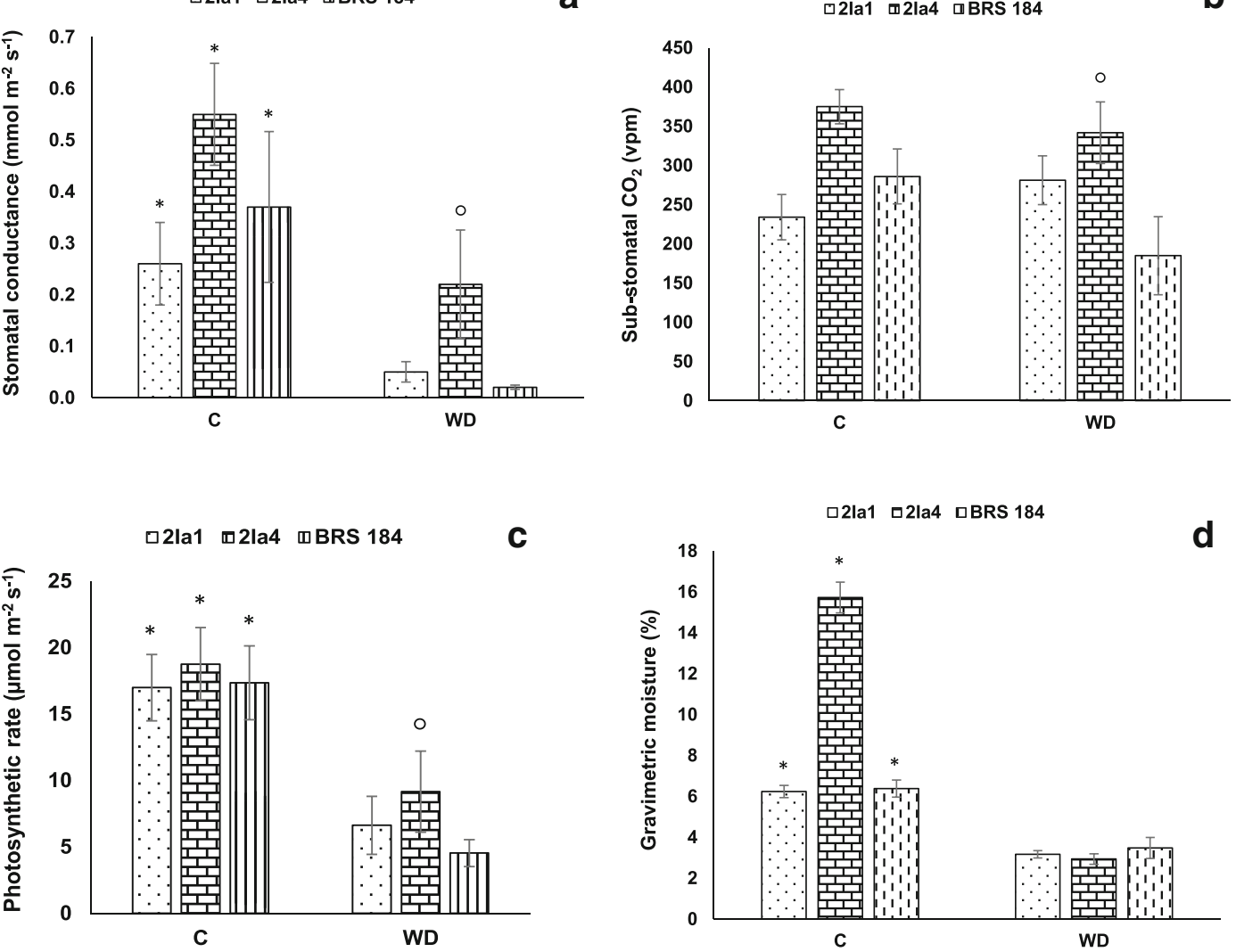

Fig. 2 Gas exchange measurements and gravimetric moisture (GrM) of the substrate-sand mixture used to grow soybean plants genetically modified with the construction AtGolS2 and their parental cultivar (BRS 184). a Stomatal conductance, b substomatal $\mathrm{CO}_{2}$, $\mathbf{c}$ photosynthetic rate, and $\mathbf{d}$ gravimetric moisture

Growth analysis of soybean plants genetically modified with the Gene AtGolS2 under WD

The soybean conventional cultivar BRS 184 and the GM lines 2Ia1 and 2Ia4 were evaluated regarding leaf blade dry matter, stem plus petiole dry matter, root dry matter, and total dry matter under $\mathrm{C}$ and WD conditions. Except for stem plus petiole dry matter, there was significant interaction between plant materials and water conditions (Table 1). Lower values were detected in almost all plants under WD regardless of the plant material evaluated. Furthermore, 2Ia4 plants had lower values in the $\mathrm{C}$ condition relative to 2Ia1 event and BRS 184 plants (Supplementary Fig. 1).

As for the number of nodes (NN), mean length of internodes, leaf area, and RGRH, there was no interaction between plant materials and water conditions, except for NN (Table 1). Lower values for all plants under b

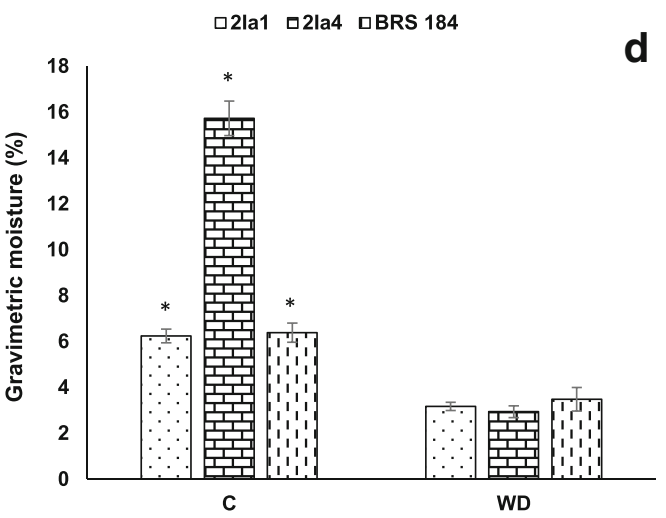

of the substrate-sand mixture. Means \pm standard error indicated by asterisk between water conditions and by circle among plant materials are significantly higher according to the Tukey test $(p \leq 0.05) ; n=9$

WD conditions were observed, regardless of the plant material evaluated (Supplementary Fig. 2).

Daily transpiration

Considering the results of daily transpiration obtained through weighing pots on successive days (Supplementary Fig. 3a), and the results of GrM (Fig. 2d), we can infer that the event 2Ia4 stored a greater volume of water under $\mathrm{C}$ conditions, while 2Ia1 and BRS 184 plants lost more water by transpiration on the first WD days. As the days went by, since the event 2Ia4 had greater volume of water stored in the substrate-sand mixture at the beginning of the irrigation withholding, these plants had higher transpiration than 2Ia1 and BRS 184 plants during the intermediate evaluation period with peak of transpiration at day 5-6. However, at the end of the 
experimental period, all materials showed a similar behavior, thus corroborating the results of GrM (Fig. 2d).

Survival rate

BRS 184 plants showed $100 \%$ mortality after 21 days of irrigation withholding, followed by 9 days of rehydration (Supplementary Fig. 3b). As for the event 2Ia1, of the eight plants evaluated, only one kept a single green trifoliate leaf after rehydration (Supplementary Fig. 3c). In turn, a higher survival rate was observed for the event 2Ia4 (Supplementary Fig. 3d).

Agronomical parameters under greenhouse and field conditions

In relation to the agronomical parameters assessed in greenhouse, no interaction between plant materials and water conditions was identified for number of pods without seeds, number of seeds per pod, and 1000 -seed weight, whereas significant interaction was detected for number of pods presenting seeds, total dry matter of seeds, and total number of seeds (Table 1). In general, higher values were observed for GM 2Ia4 and cv. BRS 184 plants regarding number of pods presenting seeds, number of pods without seeds, total dry matter of seeds, and total number of seeds (Fig. 3a-d), while no differences were identified between plant materials for number of seeds per pod and 1000-seed weight (Fig. 3e, f).

When water deficit was induced under field conditions, in relation to the number of pods with seeds and number of seeds (Fig. 4a, c), plants from the event 2Ia4 showed higher values than BRS 184, except under DSV. Furthermore, BRS 184 plants showed decreased values under DSV and DSR relative to IRR, while 2Ia4 plants showed reduction under NIRR and DSV. Considering the dry matter of pods with seeds and the dry matter of seeds (Fig. 4b, d), event 2Ia4 showed higher values relative to BRS 184 regardless of water condition. With respect to the 100 -seed weight (Fig. 4e), event 2Ia4 had higher values than BRS 184, except under DSR. In addition, both plant materials showed higher values under DSV relative to IRR. A reduction was also observed under DSR for event 2Ia4.

There was no difference in yield (Fig. 4f) between both plant materials under DSV and DSR, which was probably due to the low drought intensity during the
2014/15 crop season (Supplementary Fig. 4). However, higher values were detected for event 2Ia4 under IRR and NIRR.

Protein and oil contents tended to be similar between 2Ia4 and BRS 184 seeds regardless of water condition (Supplementary Table S4).

\section{Discussion}

Currently, the context of climatic changes in the world weather demands strategies to develop droughttolerance crops. Thus, the gene AtGolS2 was introduced into soybean plants by genetic transformation via Agrobacterium aiming to improve water deficit tolerance. Galactinol synthase (GolS) is a key enzyme in the production of raffinose family oligosaccharides (RFOs), synthesizing galactinol from UDP-galactose and myoinositol (Panikulangara et al. 2004; Pattanagul and Madore 1999). Acting as osmoprotectants, RFOs such as raffinose, stachyose, and verbascose are known to be involved in response to adverse environmental conditions, such as extreme temperatures, water deficit, and salinity. In drought tolerance, RFOs are able to regulate the osmotic potential and protect enzymes and membranes from water deficit implications in the cell metabolism (Crowe et al. 1984; Wang et al. 2004).

Usually, genetic transformation process using $A$. tumefaciens inserts a low number of copies in the host genome (Kohli et al. 2003; Olhoft et al. 2004; Oltmanns et al. 2010), as observed for GM events 2Ia1 and 2Ia4. Low copy number events showing promising results for improved tolerance are interesting to be introduced in breeding programs. Events with few copies facilitate segregation in crosses performed to introduce the interested characteristic into high-yield cultivars aiming the development of commercial varieties.

Transgene expression was confirmed in GM events; however, in 2Ia1 plants, a lower level was observed suggesting a possible mechanism of gene silencing (Fig. 1a). Barbosa et al. (2013) worked with GM soy plants, obtained via biolistic, and reported silenced plants due to the number of inserted copies, in a plant from the $\mathrm{T}_{0}$ generation. To confirm and determine which silencing mechanism might be occurring in event 2Ia1, other experiments and analyses in further generations need to be performed. After determining which silencing process happened, comparative studies could be 

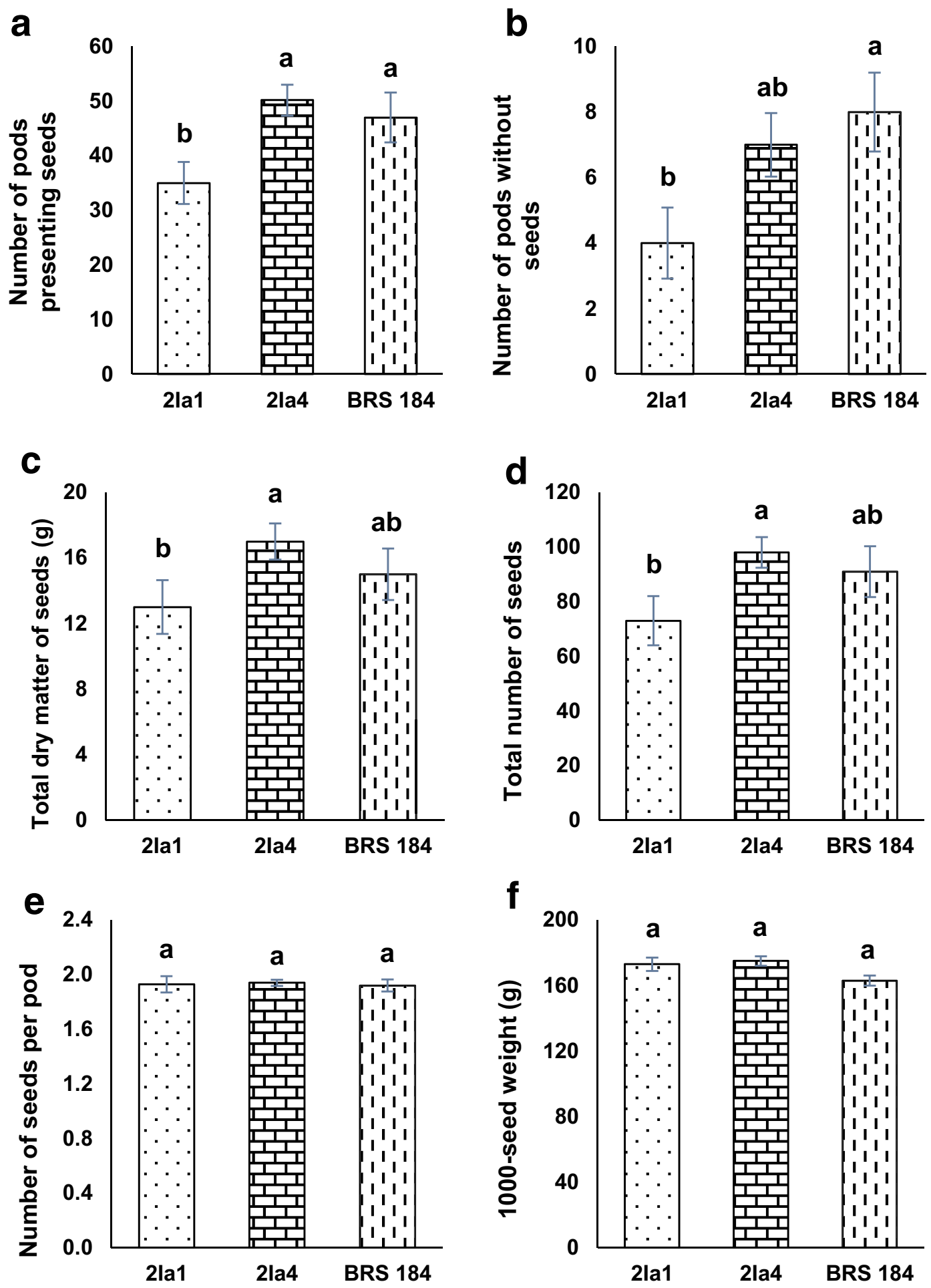

Fig. 3 Agronomical parameters (per plant) of soybean plants genetically modified with the construction AtGolS2 and their parental cultivar (BRS 184) after water deficit induced under greenhouse conditions during the vegetative period. a Number of pods presenting seeds. b Number of pods without seeds. c Total

dry matter of seeds (g). d Total number of seeds. e Number of seeds per pod. f 1000 -seed weight. Means \pm standard error followed by the same letters do not differ according to the Tukey test $(p \leq 0.05) ; n=18$ 
口BRS $184 \quad$ a2la4 GolS

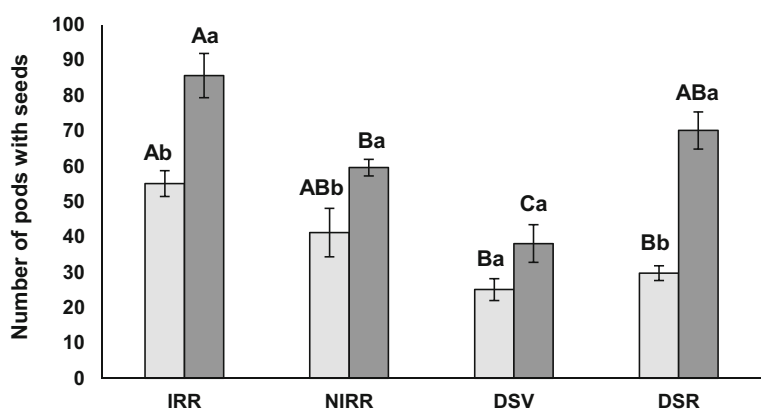

口BRS $184 \quad \square 21 \mathrm{la} 4 \mathrm{GolS}$

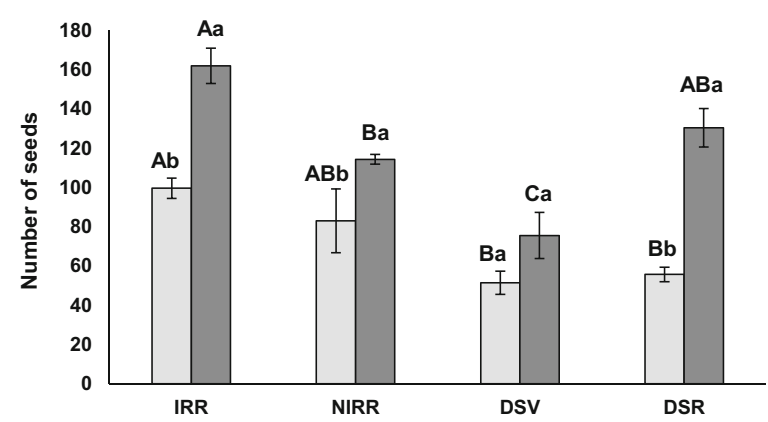

口BRS 184 口2la4 GolS

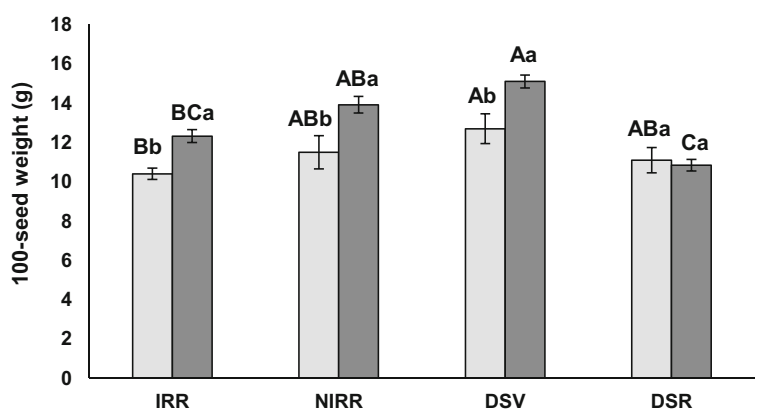

Fig. 4 Agronomical traits at harvest period of BRS 184 and 2Ia4 GolS2 plants submitted to different water regimes under field conditions which pattern is considered to be drought as opposed to the weather on 2014/15 crop season. On panels a-d, values are expressed per plant. On panels a, c, e, means \pm standard error followed by the same uppercase letter (among water conditions)

performed to verify other possible consequences of this gene silencing.

Aiming better plant performance under adverse environmental conditions, as in soybean, galactinol genes were already introduced successfully in many other plants species, in model plants but also in important

C

e a
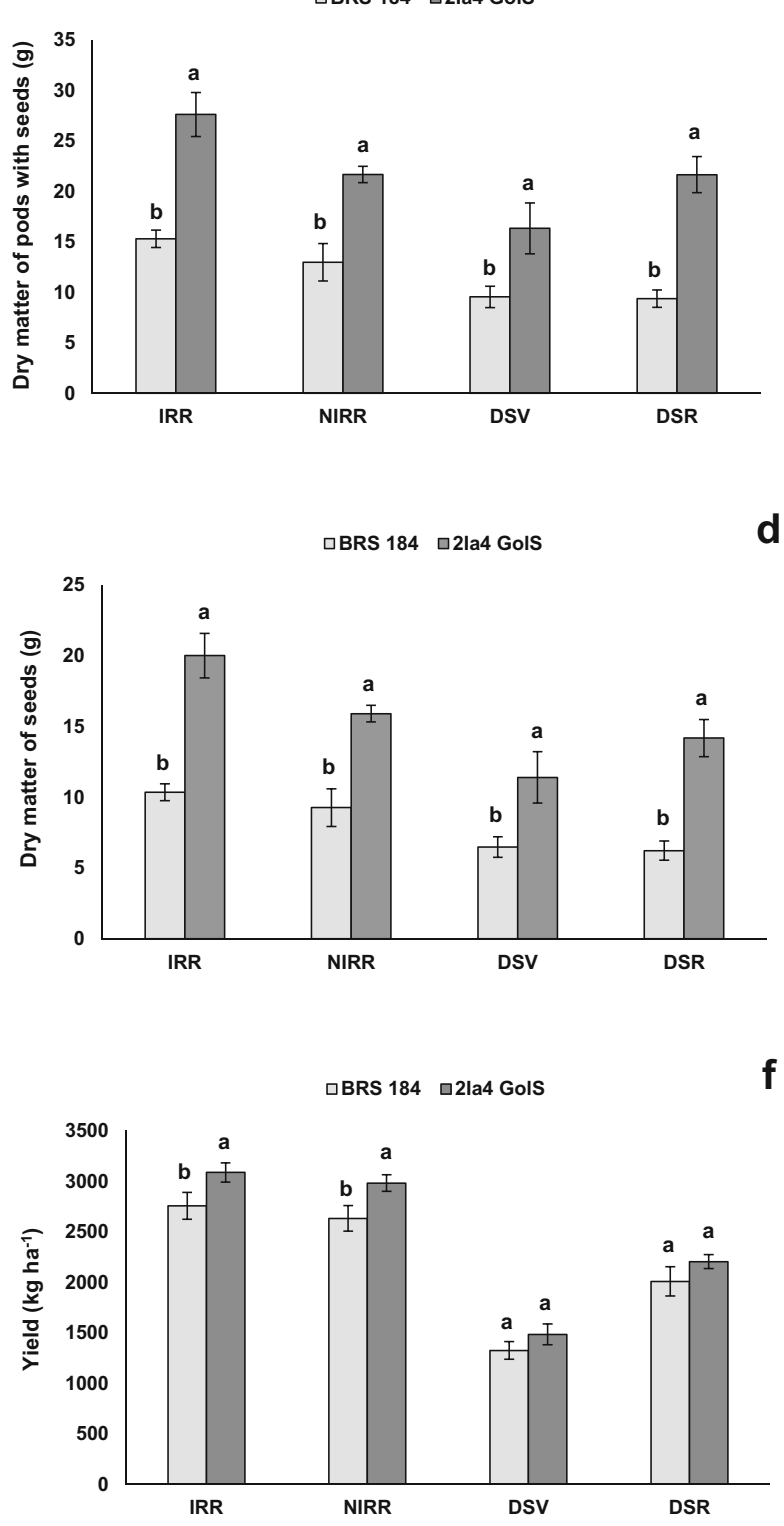

and lowercase letters (between plant materials) do not differ according to the Tukey test $(p \leq 0.05)$. On panels $\mathbf{b}, \mathbf{d}$, f, there was no significant interaction between plant materials and water conditions. Thus, on each water condition, means \pm standard error followed by the same letter (between plant materials) do not differ by the Tukey test $(p \leq 0.05) . n=4$ blocks

crops. In A. thaliana, AtGols1 and AtGols 2 mRNAs were induced by water and salt stress and the AtGols 3 mRNA was induced by cold (Taji et al. 2002). Furthermore, in M. falcata, MfGolS1 was induced by cold, and overexpression of MfGolS1 in tobacco resulted in elevated tolerance to freezing and chilling in transgenic 
plants (Zhuo et al. 2013). In rice seedlings (O. sativa), accumulation of $O s G o l S$ mRNA was reported in response to cold and to osmotic stress (Takahashi et al. 1994). In tomato (L. esculentum Mill. cv Moneymaker), dehydration induced the accumulation of LeGols-1 mRNA germinating seeds (Downie et al. 2003). In $V$. vinifera, VvGolS1 was upregulated by high temperature (Pillet et al. 2012) and, in S. miltiorrhiza, SmGolS genes presented differential expression in response to hormone, cold, and heat treatments (Wang et al. 2012). In C. arabica, $\mathrm{CaGolS}$ genes were differentially regulated under water deficit, high salt, and heat stress (dos Santos et al., 2011) and in C. canephora, CcGolS was differentially regulated by water deficit in leaves, depending on the intensity of stress and the genotype (dos Santos et al. 2015). In P. tricocarpa, GolS (PtrGolS) genes were upregulated for 2 days after the induction of water deficit treatment (Zhou et al. 2014).

In soybean submitted to water deficit, Marcolino and co-workers (2014) described a diurnal oscillation and expression induction for GmGols-like gene. Gene expression quantification for soybean GolS (Glyma19g40680) confirmed the expression induction in plants submitted to water deficit (Rodrigues et al. 2015). These reports corroborates data obtained here, as in water deficit conditions, AtGolS2 gene was highly expressed in event 2Ia4 (Fig. 1b), suggesting that AtGols2 gene might be evolved in drought response mechanism.

Therefore, an increase in the accumulation of raffinose and galactinol transcripts was noticed in plants from the soybean GM 2Ia4 event (Fig. 1b-d). The importance of galactinol and raffinose transcript accumulation due to changes in carbohydrate metabolism in abiotic stress conditions was already reported. In M. falcata, the accumulation of raffinose and stachyose was associated with the differential cold tolerance between M. falcata and $M$. sativa. In tobacco overexpressing MfGolSl, enhanced levels of galactinol, raffinose, and stachyose transcripts resulted in elevated tolerance to freezing and chilling in transgenic plants (Zhuo et al. 2013). In cucumber growing under low temperature stress, raffinose content increased gradually in the leaves, the fruits, the stems, and the roots (Suia et al. 2012). Furthermore, a considerable increase in the concentration of raffinose was detected in rice seedlings exposed to chilling for more than 4 days (Saito and Yoshida 2011).

Especially under water deficit conditions, Taji et al. (2002) described an increase of both galactinol and raffinose in the transformed plants, indicating that these sugars have a fundamental role in drought tolerance, probably acting as osmoprotectors, antioxidants, and signaling molecules (ElSayed et al. 2014). Peters et al. (2007) also observed the accumulation of sucrose and raffinose as the predominant carbohydrates in plants of Xerophyta viscosa under water deficit showing relative water content below $5 \%$. In coffee (C. canephora), leaves from a drought-tolerant genotype showed an increase in raffinose levels of almost twofold greater than in the sensitive-drought genotype, under severe stress (dos Santos et al. 2015). In P. tricocarpa, an increase of raffinose levels was observed after 4 days of water deficit treatment was reported (Zhou et al. 2014).

In addition to the role that RFOs play in drought tolerance, it is possible that the interaction between the LEA proteins (Fig. 1e, f) and RFOs (Fig. 1c, d) has made an increase in the capacity of 2Ia4 plants to survive and recover after severe drought. Wolkers and co-workers (2001) evaluated the ability of soluble carbohydrates such as sucrose and trehalose and LEA proteins to act jointly by forming glassy structures, which bind via hydrogen bonds, with the objective of minimizing the damage caused by abiotic stresses. Therefore, these researchers used infrared spectroscopy in Typha latifolia pollen and were able to conclude that the formation of these structures could protect plant cells during extreme abiotic conditions, enabling longer stability against drought in tolerant organisms. This network formed by carbohydrates and LEA proteins allows greater stability of cellular structures, serving as anchors in a molecular network to provide stability to macromolecular and cellular structures (Wolkers et al. 2001). In the cytoplasmic matrix, this glassy state would function to inhibit the fusion of cell membranes (Sun et al. 1996; Crowe et al. 1997), to prevent the denaturation of proteins (Crowe et al. 2011), and to limit the diffusion of free radicals (Liu et al. 2010; Tunnacliffe et al. 2010; Battaglia and Covarrubias 2013; Amara et al. 2013). Although sucrose and trehalose were used in the work of Wolkers et al. (2001), the researchers reported that any soluble carbohydrate could have the characteristic of forming glassy structures for cell protection.

Regarding physiological parameters, the results showed that the higher GrM values observed under well-watered conditions $(C)$ and the increase of galactinol and raffinose transcripts observed in 2Ia4 plants probably influenced the gas exchange responses 
(Fig. 2), which were not compatible with the standard corresponding to stressed plants, which show $g_{s}$ less than $200 \mathrm{mmol} \mathrm{H}_{2} \mathrm{O} \mathrm{m}^{-2} \mathrm{~s}^{-1}$ (Flexas et al. 2004; Salinet 2009). Then, such plants delayed the drought effects probably due to the accumulation of carbohydrates, which in turn acted as osmoprotectors in osmotic adjustment. According to Bray (1997), the osmotic potential is reduced in the cytosol during the osmotic adjustment, maintaining the water potential and cell turgor close to the optimal level. When turgor is maintained, processes such as stomatal conductance, $\mathrm{CO}_{2}$ assimilation rate, photosynthesis, and leaf tissue expansion are partially maintained, even under conditions of low water potential in the soil, thus assuring the plant development under stress conditions (Pattanagul and Madore 1999; Vinocur and Altman 2005; Elsayed et al. 2014). In the present study, although there was no interaction between plant materials and water conditions, we observed a decrease of the photosynthetic rate in all of the plants evaluated, which consists of one of the main responses to water deficit (Shinozaki and Yamaguchi-Shinozaki 2007). In GM soybean 2Ia4 plants, despite the photosynthetic rate being lower under water deficit, such values were higher than those of other plant materials (Fig. 2). This result can be due to the osmotic adjustment being unable to prevent the decrease in photosynthetic rate under water deficit conditions. However, the turgor maintenance, confirmed by the higher $g_{s}$ values in 2Ia4 plants, probably enabled photosynthesis and other important physiological activities to be maintained under water deficit even at low levels, thus making the carbon and nitrogen redistribution in such plants possible, as suggested by Kobata et al. (1992) and Palta et al. (1994).

Although phenotypic evaluations showed lower values in almost all plants under WD regardless of the plant material evaluated, and in some cases 2Ia4 plants had lower values in the $\mathrm{C}$ condition relative to 2Ia1 event and BRS 184 plants (Supplementary Fig. 1), we can infer that use of the constitutive promoter CaMV35S did not change the development characteristics of GM 2Ia4 plants. The constitutive promoter $35 \mathrm{~S}$ has been frequently used in the control of gene expression and, for a long time, was associated with plant growth retardation in the absence of stress (Liu et al. 1998; Kasuga et al. 1999; Kasuga et al. 2004; Morran et al. 2011). However, in soybean, under water deficit, Marinho et al. (2015) worked with GM soybean plants overexpressing the transcription factor AtAREB1 under the control of CaMV35S promoter observed that, at the end of the experimental period, there were no differences regarding root dry matter, leaf blade dry matter, and total leaf area when plants were compared under well-watered and WD conditions, indicating that such a promoter can be successfully used to obtain GM soybean plants with no growth retardation.

After rehydration, AtGols2 GM 2Ia4 plants showed $100 \%$ recovery (Supplementary Fig. 3d). Similarly, Taji et al. (2002) demonstrated that Arabidopsis plants overexpressing the gene 35S:AtGolS2 showed complete recovery after 14 days of WD followed by 5 days of rehydration due to a reduction in leaf transpiration, higher water accumulation in the substrate, and the accumulation of raffinose and galactinol in tissues, suggesting that increased levels of these carbohydrates would have allowed their effect as osmoprotectors. Such behavior might be due to the osmotic adjustment allowing these soybean plants to become more tolerant to drought since they were able to maintain development under stress conditions (Serraj and Sinclair 2002).

Yield components assessed in greenhouse showed higher values of number of pods with seeds and total number of seeds for GM 2Ia4 and BRS 184, but no differences were observed for number of seeds per pod and 100 seeds-weight for all plant materials. However, when yield components were evaluated under field in crop season 2014/2015, AtGolS2 GM event 2Ia4 presented higher values of number of pods with seeds and number of seeds (Figs. 4a, c) than those of the cv. BRS 184 and higher yield values were detected for the event 2Ia4 under IRR and NIRR conditions. As observed in our data, Passioura (2012) described that results obtained under controlled conditions in greenhouses may not be representative of the way in which plants behave over the entire season in the real field situation. In containment conditions, plants are not able to express their total potential, as limitations due to pot size and controlled water amount, temperature fluctuations, diseases, and pests do not challenge the organism as a whole, but reduce environmental real situations. In addition, when there is an objective to develop a cultivar and release it, tests in the field are a legal requirement of the Brazilian National Technical Biosafety Commission prior to approving a commercial product. Thus, it is important to test GM plants in the field to accurately gauge whether the technology is successful. 
Aside from yield, soybean producers are also searching for grain quality, as this grain remains the most important source of high-quality vegetable protein for animal feed manufacture. Through plant breeding, it has been possible to obtain protein levels between 40 and $45 \%$, and lipid levels between 18 and $20 \%$. The maintenance of these parameters is essential to be considered in the development of GM lines, as it adds value to the grain and ensures the competitiveness of soy in the world market. For GM AtGolS2 event 2Ia4, the most promising event, oil and protein content values were accepted by crushing industry, meting quality references and commercial specifications (Embrapa 2015), enabling this line to enter the feed market for poultry, pork, cattle, other farm animals, and pets.

\section{Conclusion}

The overexpression of AtGolS2 in soybean plants led to increased galactinol and raffinose transcripts, probably resulting in changes in carbohydrate metabolism. These transcripts, together with increased LEA transcripts, may have acted as osmoprotectors, protecting and stabilizing cells under water deficit, leading to higher drought tolerance and survival rate of 2Ia4 plants. In the experiment conducted under field conditions, higher yield was detected for AtGolS2 2Ia4 plants under IRR and NIRR treatments. However, new experiments, in more crop seasons, are needed to confirm the hypothesis of osmotic adjustment for improved drought tolerance, in GM 2Ia4 soybean plants. Oil and protein content in the transgenic line were not affected by the genetic introduction, ensuring their competitiveness in livestock market and enabling it to be introduced in a soybean breeding programs for the development of a commercial variety.

\footnotetext{
Acknowledgments We thank the Coordination for the Improvement of Higher Education Personnel (CAPES) for granting scholarships to PT Honna (Master's), MDC Molinari (Master's) and R Fuganti-Pagliarini (Postdoctoral fellow), and the National Council for Scientific and Technological Development (CNPq) for granting a scholarship to LC Ferreira (Postdoctoral fellow). This work was financially supported by the Science and Technology Research Partnership for Sustainable Development (SATREPS) of the Japan Science and Technology Agency (JST)/Japan International Cooperation Agency (JICA).
}

\section{References}

Amara I, Capellades M, Ludevid MD et al (2013) Enhanced water stress tolerance of transgenic maize plants over-expressing LEA Rab28 gene. J Plant Physiol 170:864-873. doi:10.1016 /j.jplph.2013.01.004

Barbosa EGG, Leite JP, Marin SRR et al (2013) Overexpression of the ABA-dependent AREB1 transcription factor from Arabidopsis thaliana improves soybean tolerance to water deficit. Plant Mol Biol Report 31:719-730. doi:10.1007 /s11105-012-0541-4

Battaglia M, Covarrubias AA (2013) Late embryogenesis abundant (LEA) proteins in legumes. Front Plant Sci 4:190. doi:10.3389/fpls.2013.00190

Bray EA (1997) Plant responses to water deficit. Trends Plant Sci 2:48-54. doi:10.1016/S1360-1385(97)82562-9

Casali N, Preston A (2003) E. coli Plasmid vectors. Plasmid 235: 55-69. doi:10.1385/1592594093

Chaves MM, Oliveira MM (2004) Mechanisms underlying plant resilience to water deficits: prospects for water-saving agriculture. J Exp Bot 55:2365-2384. doi:10.1093/jxb/erh269

Chaves MM, Maroco JP, Pereira JS (2003) Understanding plant responses to drought - from genes to the whole plant. Funct Plant Biol 30:239-264

Crowe JH, Crowe LM, Chapman D (1984) Preservation of membranes in anhydrobiotic organisms: the role of trehalose. Science 223:701-703. doi:10.1126/science.223.4637.701

Crowe JH, Oliver AE, Hoekstra FA, Crowe LM (1997) Stabilization of dry membranes by mixtures of hydroxyethyl starch and glucose: the role of vitrification. Cryobiology 35 : 20-30. doi:10.1006/cryo.1997.2020

Crowe JH, Crowe L, Carpenter JE et al (2011) Anhydrobiosis: cellular adaptation to extreme dehydration. Handb Physiol Physiol:1445-1477. doi:10.1002/cphy.cp130220

dos Santos TB, Budzinski IGF, Marura CJ, Petkowicz CLO, Pereira LFP, Vieira LGE (2011) Expression of three galactinol synthase isoforms in Coffea arabica L. and accumulation of raffinose and stachyose in response to abiotic stresses. Plant Physiol Biochem 49:441-448

dos Santos TB, Lima RB, Nagashima GT, Petkowicz CLO, Carpentieri-Pípolo V, Pereira LFP, Domingues DS, Vieira LGE (2015) Galactinol synthase transcriptional profile in two genotypes of Coffea canephora with contrasting tolerance to drought. Genet Mol Biol 38(2):182-190. doi:10.1590 /S1415-475738220140171

Downie B, Gurusinghe S, Dahal P, Thacker RR, Snyder JC, Nonogaki H, Yim K, Fukanaga K, Alvarado V, Bradford KJ (2003) Expression of a GALACTINOL SYNTHASE gene in tomato seeds is up-regulated before maturation desiccation and again after imbibition whenever radicle protrusion is prevented. Plant Physiol 131:1347-1359

Doyle JJ, Doyle JL (1987) A rapid DNA isolation procedure for small quantities of fresh leaf tissue. Phytochem Bull 19:11-15

Elsayed AI, Rafudeen MS, Golldack D (2014) Physiological aspects of raffinose family oligosaccharides in plants: protection against abiotic stress. Plant Biol 16:1-8. doi:10.1111 /plb.12053

Embrapa S (2015) Comunicado Tecnico 86. Teores de oleo e proteina em soja: fatores envolvidos e qualidade para a industria. ISSN. 2176-2889 
Fang Y, Xiong L (2015) General mechanisms of drought response and their application in drought resistance improvement in plants. Cell. Mol. Life Sci., 72:673-689. doi:10.1007 /s00018-014-1767-0

Fehr WR, Caviness CE, Burmood DT, Pennington JS (1971) Stage of development description for soybeans, Glycine $\max ($ L.) Merril. Crop Sci 11:929-931. doi:10.2135 /cropsci1971.0011183X001100060051x

Flexas J, Bota J, Loreto F et al (2004) Diffusive and metabolic limitations to photosynthesis under drought and salinity in $\mathrm{C} 3$ plants. Plant Biol 6:269-279. doi:10.1055/s-2004-820867

Heil C (2010) Rapid, multi-component analysis of soybeans by FT-NIR spectroscopy. Thermo Fisher Scientific, Madison, p. 3 (Application note: 51954)

Hood EE, Gelvin SB, Melchers LS, Hoekema A (1993) New agrobacterium helper plasmids for gene transfer to plants. Transgenic Res 2:208-218. doi:10.1007/BF01977351

$\mathrm{Hu}$ H, Xiong L (2014) Genetic engineering and breeding of drought-resistant crops. Annu Rev Plant Biol 65:715-741. doi:10.1146/annurev-arplant-050213-040000

Kasuga M, Liu Q, Miura S et al (1999) Improving plant drought, salt, and freezing tolerance by gene transfer of a single stressinducible transcription factor. Nat Biotechnol 17:287-291. doi:10.1038/7036

Kasuga M, Miura S, Shinozaki K, Yamaguchi-Shinozaki K (2004) A combination of the Arabidopsis DREB1A gene and stressinducible rd29A promoter improved drought- and lowtemperature stress tolerance in tobacco by gene transfer. Plant Cell Physiol 45:346-350. doi:10.1093/pcp/pch037

Kohli A, Twyman RM, Abranches R et al (2003) Transgene integration, organization and interaction in plants. Plant Mol Biol 52:247-258

Liu J-JJ, Krenz DC, Galvez AF, Lumen BOD (1998) Galactinol synthase (GS): increased enzyme activity and levels of mRNA due to cold and desiccation. Plant Sci 134:11-20. doi:10.1016/s0168-9452(98)00042-9

Liu Y, Zheng Y, Zhang Y et al (2010) Soybean PM2 protein (LEA3) confers the tolerance of Escherichia coli and stabilization of enzyme activity under diverse stresses. Curr Microbiol 60:373-378. doi:10.1007/s00284-009-9552-2

Marcolino-Gomes J, Rodrigues FA, Fuganti-Pagliarini R, Bendix C, Nakayama TJ, Celaya B, Hugo Molinari BC, Oliveira MCN, Harmon FG, Nepomuceno AL (2014) Diurnal oscillations of soybean circadian clock and drought responsive genes. PLoS One 9(1). doi:10.1371/journal.pone.0086402

Marinho JP, Kanamori N, Ferreira LC et al (2015) Characterization of molecular and physiological responses under water deficit of genetically modified soybean plants overexpressing the AtAREB1 transcription factor. Plant Mol Biol Rep. doi:10.1007/s11105-015-0928-0

Morran S, Eini O, Pyvovarenko T et al (2011) Improvement of stress tolerance of wheat and barley by modulation of expression of DREB/CBF factors. Plant Biotechnol J 9:230 249. doi:10.1111/j.1467-7652.2010.00547.x

Olhoft PM, Flagel LE, Somers DA (2004) T-DNA locus structure in a large population of soybean plants transformed using the agrobacterium-mediated cotyledonary-node method. Plant Biotechnol J 2:289-300. doi:10.1111/j.14677652.2004.00070.x

Oltmanns H, Frame B, Lee L-Y et al (2010) Generation of backbone-free, low transgene copy plants by launching T-DNA from the agrobacterium chromosome. Plant Physiol 152: 1158-1166. doi:10.1104/pp.109.148585

Palta JA, Kobata T, Turner NC, Fillery IR (1994) Remobilization of carbon and nitrogen in wheat as influenced by postanthesis water deficits. Crop Sci 34:118-124. doi:10.2135 /cropsci1994.0011183X003400010021x

Panikulangara TJ, Eggers-Schumacher G, Wunderlich M, Stransky H, Schoffl F (2004) Galactinol synthase1. A novel heat shock factor target gene responsible for heat-induced synthesis of raffinose family oligosaccharides in Arabidopsis. Plant Physiol 136:3148-3158

Passioura JB (2012) Phenotyping for drought tolerance in grain crops: when is it useful to breeders? Funct Plant Biol 39:851859. doi:10.1071/FP12079

Pattanagul W, Madore MA (1999) Water deficit effects on raffinose family oligosaccharide metabolism in coleus. Plant Physiol 121:987-993. doi:10.1104/pp.121.3.987

Paz MM, Martinez JC, Kalvig AB et al (2006) Improved cotyledonary node method using an alternative explant derived from mature seed for efficient Agrobacterium-mediated soybean transformation. Plant Cell Rep 25:206-213. doi:10.1007/s00299-005-0048-7

Peters S, Mundree SG, Thomson JA et al (2007) Protection mechanisms in the resurrection plant Xerophyta viscosa (Baker): both sucrose and raffinose family oligosaccharides (RFOs) accumulate in leaves in response to water deficit. J Exp Bot 58:1947-1956. doi:10.1093/jxb/erm056

Pfaffl MW (2001) A new mathematical model for relative quantification in real-time RT-PCR. Nucleic Acids Res 29:e45. doi:10.1093/nar/29.9.e45

Pillet J, Egert A, Pieri P, Lecourieux F, Kappel C, Charon J, Gomes E, Keller F, Delrot S, Lecourieux D (2012) VvGOLS1 and VvHsfA2 are involved in the heat stress responses in grapevine berries. Plant Cell Physiol 53:1776-1792

Rech EL, Vianna GR, Aragão FJL (2008) High-efficiency transformation by biolistics of soybean, common bean and cotton transgenic plants. Nat Protoc 3(3):1-10

Rodrigues FA, Fuganti-Pagliarini R, Marcolino-Gomes J, Nakayama TJ, Molinari HBC, Lobo FP, Harmon FG, Nepomuceno AL (2015) Daytime soybean transcriptome fluctuations during water deficit stress. BMC Genomics 16: 505. doi:10.1186/s12864-015-1731-x

Saito M, Yoshida M (2011) Expression analysis of the gene family associated with raffinose accumulation in rice seedlings under cold stress. Short communication. J Plant Physiol 168(18):2268-2271

Salinet LH (2009) Avaliação fisiológica e agronômica de soja geneticamente modificada para maior tolerância à seca. Universidade de São Paulo

Serraj R, Sinclair TR (2002) Osmolyte accumulation: can it really help increase crop yield under drought conditions? Plant Cell Environ 25:333-341. doi:10.1046 /j.1365-3040.2002.00754.x

Shinozaki K, Yamaguchi-Shinozaki K (2007) Gene networks involved in drought stress response and tolerance. J Exp Bot 58:221-227. doi:10.1093/jxb/erl164

Suia X, Menga F, Wanga H, Weia Y, Lia R, Wanga Z, Hua L, Wangb S, Zhanga Z (2012) Molecular cloning, characteristics and low temperature response of raffinose synthase gene in Cucumis sativus L. J Plant Physiol 16(18):1883-1891 
Sun WQ, Leopold AC, Crowe LM, Crowe JH (1996) Stability of dry liposomes in sugar glasses. Biophys J 70:1769-1776. doi:10.1016/S0006-3495(96)79740-0

Taji T, Ohsumi C, Iuchi S et al (2002) Important roles of droughtand cold-inducible genes for galactinol synthase in stress tolerance in Arabidopsis thaliana. Plant J 29:417-426. doi:10.1046/j.0960-7412

Takahashi R, Joshee N, Kitagawa Y (1994) Induction of chilling resistance by water stress, and cDNA sequence analysis and expression of water stress regulated genes in rice. Plant Mol Biol 26:339-352

Thornthwaite CW, Mather JR (1955) The water balance. Laboratory of Climatology, Centerton

Tran L-SP, Nishiyama R, Yamaguchi-Shinozaki K, Shinozaki K (2010) Potential utilization of NAC transcription factors to enhance abiotic stress tolerance in plants by biotechnological approach. GM Crops 1:32-39. doi:10.4161/gmcr.1.1.10569

Tunnacliffe A, Hincha DK, Leprince O, Macherel D (2010) LEA proteins: versatility of form and function. In: Lubzens E, Cerda J, Clark M (eds) dormancy and resistance in harsh environments. Springer, Heidelberg. Top Curr Genet 21:91108. doi:10.1007/978-3-642-12422-8_6

Turner N, Wright G, Siddique K (2001) Adaptation of grain legumes (pulses) to water-limited environments. Adv Agron 71:123-231. doi:10.1016/S0065-2113(01)71015-2

Vinocur B, Altman A (2005) Recent advances in engineering plant tolerance to abiotic stress: achievements and limitations. Curr Opin Biotechnol 16:123-132. doi:10.1016/j. copbio.2005.02.001
Wang S, Wan C, Wang Y et al (2004) The characteristics of Na+, $\mathrm{K}+$ and free proline distribution in several drought-resistant plants of the Alxa Desert, China. J Arid Environ 56:525-539. doi:10.1016/S0140-1963(03)00063-6

Wang D, Yao W, Song Y, Liu W, Wang Z (2012) Molecular characterization and expression of three galactinol synthase genes that confer stress tolerance in Salvia miltiorrhiza. J Plant Physiol 169:1838-1848

Wang X, Chen H, Sha A et al (2015) Laboratory testing and molecular analysis of the resistance of wild and cultivated soybeans to cotton bollworm, Helicoverpa armigera (Hübner). The Crop Journal 3:19-28. doi:10.1016/j. cj.2014.08.004

Wolkers WF, McCready S, Brandt WF et al (2001) Isolation and characterization of a D-7 LEA protein from pollen that stabilizes glasses in vitro. Biochim Biophys Acta - Protein Struct Mol Enzymol 1544:196-206. doi:10.1016/S01674838(00)00220-X

Zhou J, Yang Y, Yu J, Wang L, Yu X, Ohtani M, Kusano M, Saito K, Demura T, Zhuge Q (2014) Responses of Populus trichocarpa galactinol synthase genes to abiotic stresses. J Plant Res 127:347-358. doi:10.1007/s10265-013-0597-8

Zhuo C, Wang T, Lu S, Zhao Y, Li X, Guo Z (2013) A cold responsive galactinol synthase gene from Medicago falcata (MfGolS1) is induced by myo-inositol and confers multiple tolerances to abiotic stresses. Physiol Plant 149(1):67-78. doi:10.1111/ppl.12019 